\title{
An analysis of influence of lack of the electricity supply to reefer containers serviced at sea ports on storing conditions of cargoes contained in them
}

\author{
Lyudmyla Filina, Ph. D. \\ Sergiy Filin, Prof. \\ Szczecin University of Technology
}

\begin{abstract}
Servicing the reefer containers at sea ports requires more reliability and precision than servicing the conventional ones because of specificity of perishable cargoes shipped in them. This paper is aimed at making analysis of way of servicing the reefer containers stored at sea port and at investigating its influence on storing conditions of refrigerated cargoes contained in them. Lack of the electricity supply to refrigerating unit of reefer container is one of the most common extraordinary situations in port area, which may lead to loss of quality of cargo contained in the container. On the basis of scenarios of possible progress of such situations, elaborated by means of calculations, rate of change of temperature of cargo in reefer containers cut-off from electricity supply source was determined and relevant recommendations as to organization of sevicing such containers at sea port, were elaborated.
\end{abstract}

Keywords: sea port, reefer container, refrigerated cargo, risk factors

\section{INTRODUCTION}

The observed rise of living standards of people results in growing consumption of perishable food products, e.g. tropical fruits [13]. Most of such goods is transported in reefer containers to Europe from different countries of Asia, Africa, South America, etc.

Containerization which has been spread over worldwide cargo shipping, has contributed to increased share of sea shipping in cargo turnover in sea ports, including that of containerized cargo, a.o. in Polish ports. Reefer containers constitute about $7-15 \%$ of total number of containers handled by Polish sea ports [7].

Among commonly known merits of shipping the goods in containers, as compared with bulk and general cargo shipping, the following can be numbered: shorter period of transport, cost reduction and increased level of safety $[2,3]$. For shipping the perishable cargoes to ensure an appropriate level of cargo safety is of crucial importance.

Cold chain of perishable cargoes shipped in containers consists of various links of moving and servicing the containers, located along the route ranging from place of collection or production of goods to consumer site. Sea ports play an important role in the chain; they should be adjusted to servicing the growing number of reefer containers, that will result in rising level of complexity of cargo servicing technology in ports. Although cost of cargo shipping in reefer containers is higher as compared with that in reefer ship holds [10], experts predict that the trend of increasing amount of shipping of the kind will be maintained at least up to the the year 2020 [9].
Such goods as meat, fishes, butter are as a rule transported in the frozen state at the temperature from $-18{ }^{\circ} \mathrm{C}$ to $-30{ }^{\circ} \mathrm{C}$, whereas vegetables and fruits in the state of chilling at the temperature from $0{ }^{\circ} \mathrm{C}$ to $+15^{\circ} \mathrm{C}$. In the subject-matter literature cargoes which require constant storing temperature are called refrigerated cargoes [9, 13]. Unkeeping the conditions of shipping and storing such cargoes leads to loss of their quality features.

Reefer containers are intended for shipping the cargoes which require determined conditions of shipping, such as the maintaining of cargo storing temperature, humidity and rate of air exchange, etc, constant [1]. As cargoes in reefer containers are very valuable and have a limited period of validity the servicing of such containers should be done fast and reliably. As compared with the servicing of conventional cargoes the servicing of containerized refrigerated cargoes requires additional operations, a.o.: permanent connection of reefer container to an electicity supply source, regular control of its technical state etc.

In Poland the existing container terminals and those presently built as well, are modernized [3,7]. However infrastructure of sea ports undergoes changes slower than structure of cargoes handled in the ports, that results in generating new problems. If the phenomenon is additionally accompanied by lack of experience or insufficient qualifications of port personnel (port management, operators, distributors etc, i.e. strong impact of human factor) or disregarding valid regulations, then risk level of loss of quality of the cargoes dramatically increases. If it exceeds an acceptable level the refrigerated cargo can lose its business value. If quality features of refrigerated cargo are 
lost through port's fault, the port should pay compensation to the cargo's owner. Occurrence of such situations results in a damage to reputation of the port, that is associated with possible resignation from services of the port by its clients. This paper is aimed at making analysis of the way the reefer containers are serviced in port and at investigating its influence on conditions of storing the cargoes contained in them.

\section{RISK FACTORS WHICH OCCUR DURING SERVICING THE REEFER CONTAINERS IN SEA PORTS}

Depending on size of a port and its organization of cargo servicing, reefer container stays in port for a few hours or several days at most. During this time it is moved from one to another element of port's infrastructure, such as ship, quay, temporary storing place, veterinary border checkpoint (GPKW) and/or custom checkpoint, in/out - gateway to port area. Moreover, on store place the containers are stored in two (rarely in three) layers where they are rearranged in the case of necessity to manipulate containers placed in lower layers. Every operation of handling and rearranging a container is associated with cuttin-off it from the electicity supply source. Number and duration time of the operations depends on a given servicing chain of the containers.

The schematic diagram shown in Fig. 1 constitutes a basis for building rational servicing chains of container during its dislocation over port area with taking into account a current state of infra- and supra-structure of the port. This is an example scheme which is typical for many European ports, that does not prevent it from its possible extension or simplification. In fact, before starting the servicing process of reefer containers it is difficult to precisely determine chain of its servicing as occurrence of risk factors may result in changing sequence and way of realization of its particular links.

Occurrence of risk factors concerning loss of quality features of containerized refrigerated cargoes in port area can be caused by:

$\star$ incorrect functioning the reefer container due to a.o. unserviceability of elements of its refrigerating unit or failures of its box structure $\star$ incorrect servicing the container and its cargo in port, resulting from negative impact of human factor etc.

The risk factors can be classified in a few ways [5, 8]. These authors propose to distinguish the following (Tab. 1):

$>$ human factors (CL) - subjective risk factors

$>$ technical and technological factors (CTT) - objectivesubjective risk factors which are most difficult to be analyzed

$>$ natural and climatic factors $(\mathrm{CPK})$ - objective risk factors.

Range of development scenarios of extraordinary situations during servicing the reefer container is relatively broad as in sea ports various combinations of risk factors can happen [4, 7]. For instance, such situations may be associated with exceedance of permissible period of disconnection of the container from the electicity supply source, failure of its refrigerating unit or mechanical failures of its box structure, incorrect cargo storing conditions etc. And, such situations may also arise a.o. from a high level of uncertainty of information obtained by port personnel from its management. Among various hazardous situations one of the most often met is lack of the electicity supply to the container being on port store place.

\section{LACK OF THE ELECTICITY SUPPLY TO THE CONTAINER STORED ON PORT STORE PLACE}

During its transport the reefer container is to be connected with an electicity supply source. In road transport the reefer containers are sometimes supplied from the truck's electric network or (often) by means of portable electric generators of GENSET type, however such generators are not moved together with the containers along its entire shipping route. During sea voyage the containers are supplied from ship's electric power network, and at container terminal - from electric power network of a given port. Certain sea ports are equipped with own GENSET generators, then the container can be connected with the GENSET unit in the case of lack of free electicity supply terminals on store place [5].

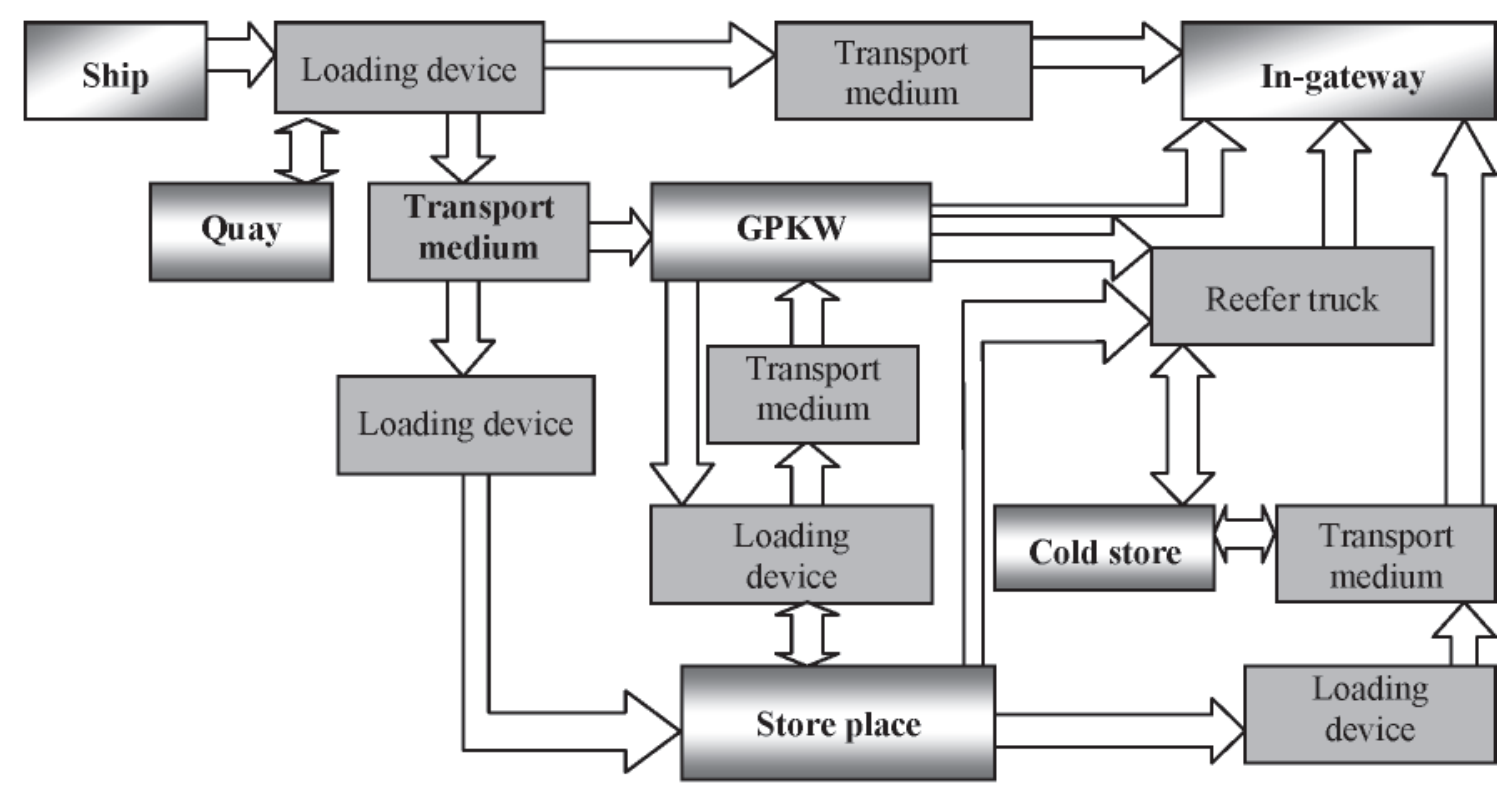

$\square$ - elements of port infrastructure $\square$ - elements of port

Fig.1. Dislocations of reefer containers over port area in the frame of various schemes of their servicing 
Tab. 1. Examples of occurrence of extraordinary situations acc. to the groups of risk factors

\begin{tabular}{|c|c|c|}
\hline $\begin{array}{l}\text { Group of } \\
\text { factors }\end{array}$ & $\begin{array}{l}\text { Selected examples of occurrence } \\
\text { of extraordinary situations }\end{array}$ & Illustrations \\
\hline 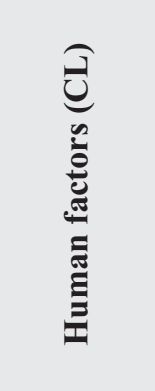 & $\begin{array}{l}\text { Incompetent servicing the container, that leads to } \\
\text { a failure of its cooling unit or its cutting-off from } \\
\text { the electicity supply source. } \\
>\text { Incompetent servicing the container, that leads to } \\
\text { a longer period of technological cutting-off the } \\
\text { container from the electicity supply source. } \\
>\text { Faults in setting the cargo storing temperature } \\
>\text { Non-tight closing the container's doors } \\
>\text { Long period of opening the container's doors } \\
>\text { Burglary of content of the container etc. }\end{array}$ & \\
\hline 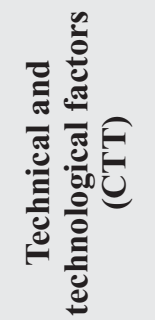 & $\begin{array}{l}\text { Failure of the container's box resulting from } \\
\text { material ageing process } \\
>\text { Failure of the container's refrigerating unit } \\
>\text { Failure of the electicity supply socket to the } \\
\text { container } \\
>\text { Failure of cargo loading device } \\
>\text { Failure of platform truck etc. }\end{array}$ & \\
\hline 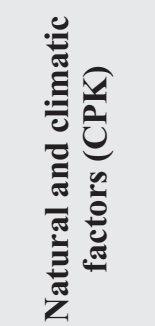 & $\begin{array}{l}\text { Shorting in the terminal's electicity supply } \\
\text { network, resulting from peneration of water } \\
>\text { Overrun period of container servicing in port } \\
\text { because of unfavourable atmospheric conditions } \\
>\text { Change in spatial position of the container leading } \\
\text { to shift of cargo contained in it etc. }\end{array}$ & \\
\hline
\end{tabular}

As showed by a functioning analysis of container terminals at Polish and Ukrainian sea ports, container's disconnection from the electicity supply source can last from $2 \mathrm{~h}$ to $4 \mathrm{~h}$ even in the case of standard unloading operation of the container from ship to quay. Sometimes it happens that containers prepared to be unloaded out of the ship are disconnected from supply source a few hours before the ship's arrival to the port. Disconnection of container from supply source before loading is a necessary technological operation (Fig. 2) and it is not taken as extraordinary one if only an allowable period of lack of the electicity supply is not exceeded. However similar situation may result form breaking the shipping regulations and official duties. For instance, operator resigns from connecting the container with port's electric power network in order to make some financial savings, knowing that within several hours the container will be removed from store place and reloaded onto a receiver's transport medium. The receiver's truck may be delayed due to a traffic jam on the roads leading to port and in consequence the period of lack of the electicity supply to the container may increase to $6 \div 8 \mathrm{~h}$. The classification of causes of container's cutting-off from the electicity supply source is given in Tab. 2. Technological disconnections of containers are short-lasting and expectable, however random disconnections may last long time and thus be hazardous.

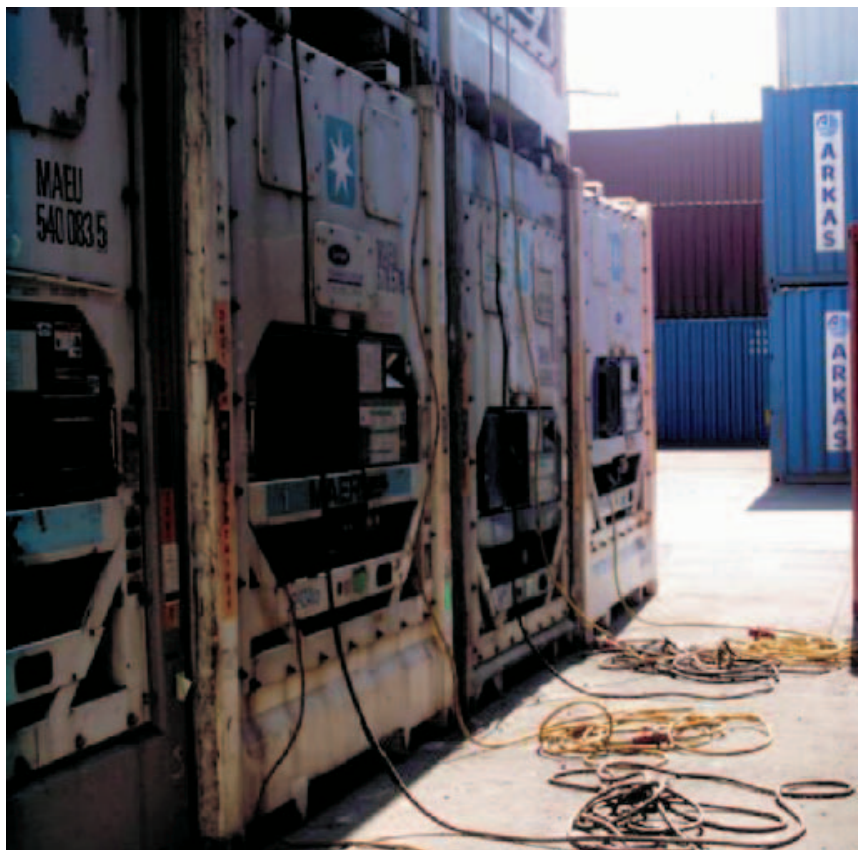

Fig. 2. Reefer containers cut-off from the electicity supply source on store place 
Tab. 2. Classification of causes of cutting-off loaded reefer container from the electicity supply source during its servicing at port

\begin{tabular}{|c|c|}
\hline \begin{tabular}{c|} 
Types of \\
container \\
disconnections
\end{tabular} & $\begin{array}{l}\text { Causes of container disconnection } \\
\text { (cutting-off) }\end{array}$ \\
\hline Technological & $\begin{array}{l}\text { 1. Loading / unloading operation } \\
\text { of container to/from the ship } \\
\text { 2. Dislocation of container over port area } \\
\text { 3. Change of container's position } \\
\text { on store place } \\
\text { 4. Custom control (veterinary one)* } \\
\text { 5. Reloading the container's content } \\
\text { 6. Loading operation of container } \\
\text { onto a truck or railway platform }\end{array}$ \\
\hline $\begin{array}{l}\text { Random and } \\
\text { forced }\end{array}$ & $\begin{array}{l}\text { 1. Lack of electricity } \\
\text { in port electric power network } \\
\text { 2. Lack of electric sockets } \\
\text { to connect containers on store place } \\
\text { 3. Failure of electric power network } \\
\text { on store place (bay or cable) } \\
\text { 4. Repair of container's refrigerating unit }\end{array}$ \\
\hline $\begin{array}{l}\text { Random but } \\
\text { not forced }\end{array}$ & $\begin{array}{l}\text { 1. Negligence of official duties by port } \\
\text { personnel (they have forgotten } \\
\text { or not wanted to connect) } \\
\text { 2. Random cut-off the electicity supply } \\
\text { cable due to vibration or catching the } \\
\text { cable by a vehicle or person. }\end{array}$ \\
\hline \multicolumn{2}{|c|}{$\begin{array}{l}\text { * In certain ports the GPKW is fitted with electric sockets for connecting } \\
\text { reefer containers. It is assumed that the above given, bold marked, } \\
\text { situations are associated with lack of possible use of a GENSET electric } \\
\text { generating set. }\end{array}$} \\
\hline
\end{tabular}

Let us consider a few examples of scenarios of developing the extraordinary situations connected with lack of the electicity supply to the reefer container on port store place.

\section{Example 1. Failure of electric cable supplying the container}

During servicing process of containers in a port a container hoisting vehicle caught electric cable supplying the reefer container stored on store place. It resulted in mechanical failure of the cable and cutting-off the container from the electicity supply source (Fig. 3).

\section{Example 2. Lack of free bays on store place}

In a sea port turnover of reefer containers has increased. The port's infrastructure is not adjusted to cope with the increasing number of containers. After unloading the containers from the ship it appeared that all bays fitted with electric sockets to connect the containers on store place were occupied since a receiver did not take away on schedule the preceding batch of containers. Several containers were not connected with the electicity supply source for $10 \mathrm{~h}$.

As observed from the above presented examples, most extraordinary situations result from human factors.

\section{COMPUTATIONAL ANALYSIS OF RATE OF TEMPERATURE CHANGES INSIDE THE DISCONNECTED REEFER CONTAINER}

In order to assess quantitatively rate of temperature changes of cargo contained in the disconnected reefer container the software „Kontener chłodniczy” (Reefer container) written in QBASIC language, was elaborated. A mathematical model realized by the software is based on the heat balance method. As showed in [5], in the container disconnected from the electricity source only three heat fluxes are present ${ }^{1)}: Q_{1}$ - heat flux flowing through container's insulation, $\mathrm{Q}_{5}$ - heat flux resulting from cargo breathing (it concerns fruits and vegetables only) oraz $\mathrm{Q}_{4}$ - heat flux for heating or cooling the cargo and its package. If to simplify and disregard the ,cold” accumulated in evaporator

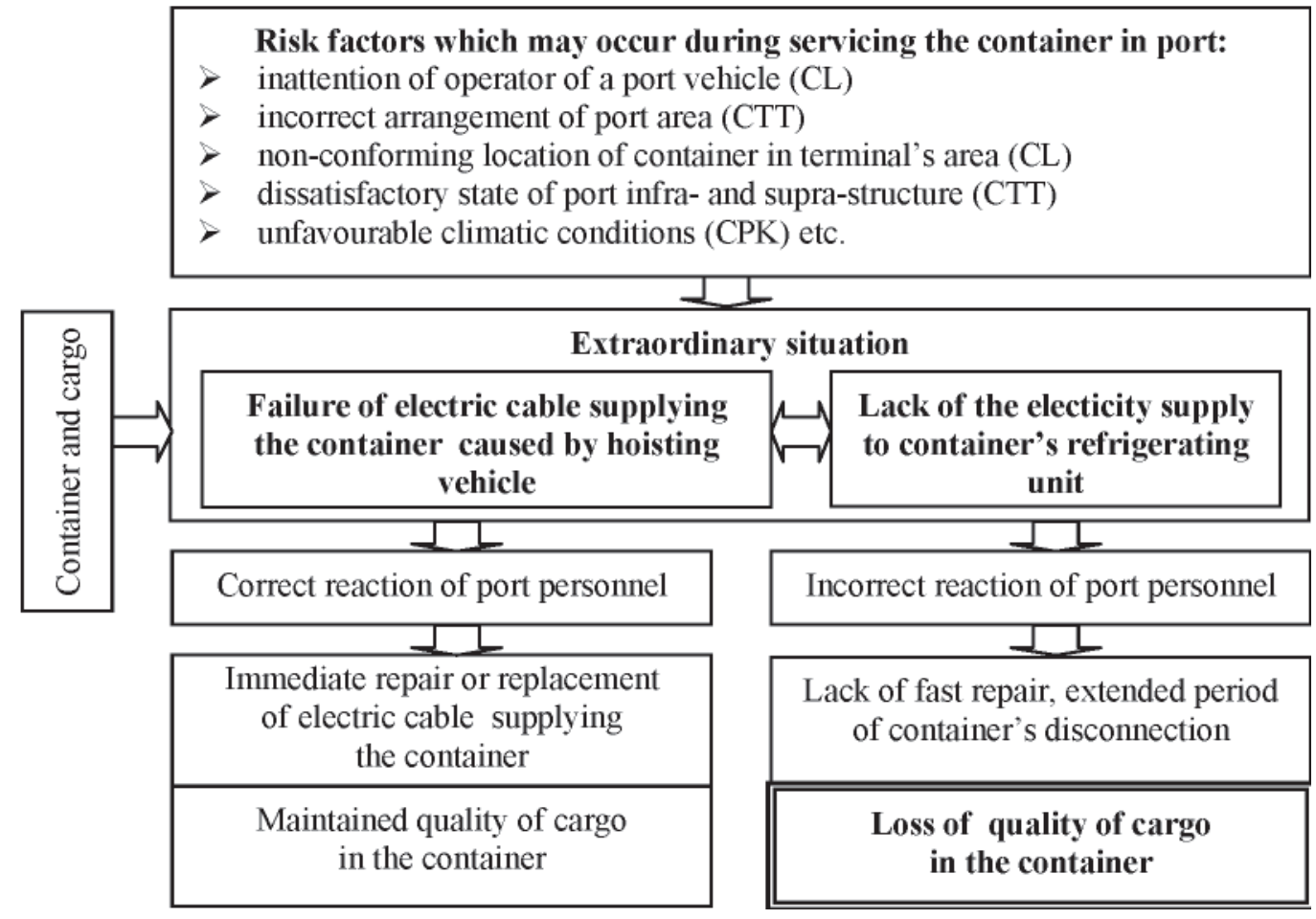

Fig. 3. Model of development scenario of an extraordinary situation during storing the container in port area (concerning failure of electric cable supplying the container)

\footnotetext{
${ }^{1)}$ In container under work up to ten heat balance components may appear.
} 


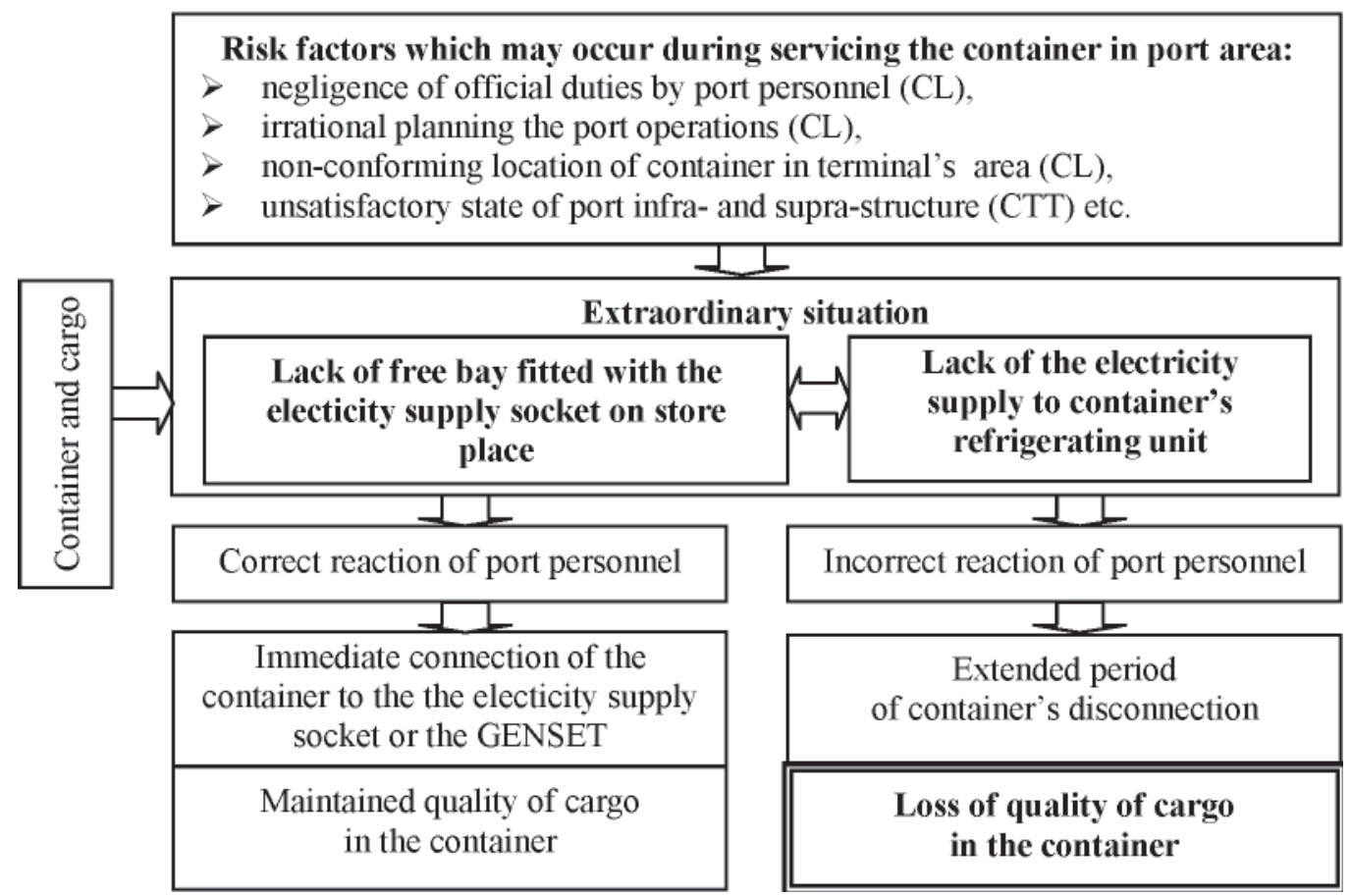

Fig. 4. Model of development scenario of an extraordinary situation during storing the container in port area (the situation dealing with lack of free bays fitted with the electicity supply socket on store place)

of refrigerating unit, the container's heat balance during the period of its disconnection will be as follows:

$$
\mathrm{Q}_{1}+\mathrm{Q}_{5}=\mathrm{Q}_{4}
$$

where:

$$
\begin{gathered}
\mathrm{Q}_{1}=\mathrm{KF}\left[\mathrm{t}_{\mathrm{ot}}-\mathrm{t}_{\mathrm{w}}(\tau)\right] \\
\mathrm{Q}_{5}=\mathrm{m}_{\mathrm{lad}} \mathrm{q}_{\mathrm{od}} \mathrm{e}^{\mathrm{k}\left[\mathrm{t}_{\mathrm{w}}(\tau)-273\right]} \\
\mathrm{Q}_{4}=\frac{\left(\mathrm{m}_{\mathrm{lad}} \mathrm{c}_{\mathrm{lad}}+\mathrm{m}_{\mathrm{op}} \mathrm{c}_{\mathrm{op}}\right)\left[\left(\mathrm{t}_{\mathrm{w}}(\tau)-\mathrm{t}_{\mathrm{p}}\right]\right.}{\tau}
\end{gathered}
$$

$\mathrm{K} \quad-$ overall heat-transfer coefficient of a container

$\mathrm{F} \quad-$ heat exchange area

$\mathrm{t}_{\mathrm{ot}} \quad-$ ambient temperature

$\mathrm{t}_{\mathrm{w}} \quad-$ temperature inside a container, which is assumed equal to mean temperature of cargo

$t_{p} \quad-$ set temperature of cargo storing (transporting), which is equal to mean temperature of cargo in the instant of cutting off the container from the electricity supply source

$\mathrm{m}_{\text {lad }} ; \mathrm{m}_{\mathrm{op}}-$ mass of cargo and its package, respectively

$\mathrm{c}_{\text {lad }} ; \mathrm{c}_{\mathrm{op}}{ }^{\mathrm{op}}-$ specific heat capacity of cargo and its package, respectively

$\mathrm{q}_{\text {od }} \quad-$ specific heat of breathing

$\mathrm{k}-$ coefficient in the relation between breathing heat and temperature

$\tau \quad-$ running time counted from the instant of cutting off the container from the electricity supply source.

By solving Eq. (1) with respect to $t_{w}$, the relations of changes of temperature inside the cut-off container in function of time, were obtained.

The elaborated software makes it posssible to introduce various kinds of cargoes and packages, various types of containers, as well as to take into account different conditions of heat exchange through particular walls of container, resulting from e.g. their insolation.

\footnotetext{
2) e.g. as a result of its getting damp.

3) it is typical for cargoes which require intensive ventilation.
}

Some results obtained by means of the computational relations are graphically presented in Fig. $5 \div 7$. The diagrams of Fig. 5 show that after cutting-off the 20' container from electricity supply source the period of reaching the critical temperature by the cooled cargo (bananas) changes from $21 \mathrm{~h}$ in the case of favourable conditions (moderate ambient temperature of $+25^{\circ} \mathrm{C}$, no insolation, state of container's insulation complies with the relevant standards $\left(\mathrm{K}=0.4 \mathrm{~W} / \mathrm{m}^{2} \cdot \mathrm{K}\right)$ as well as the container is full of cargo) down to $6 \mathrm{~h}$ in the case of unfavourable conditions \{high ambient temperature, insolation, bad state of container's insulation $\left(\mathrm{K}=0.7 \mathrm{~W} / \mathrm{m}^{2} \cdot \mathrm{K}\right)^{2)}$ as well as the container is half- filled with cargo with respect to its maximum load capacity $\left.{ }^{3)}\right\}$.

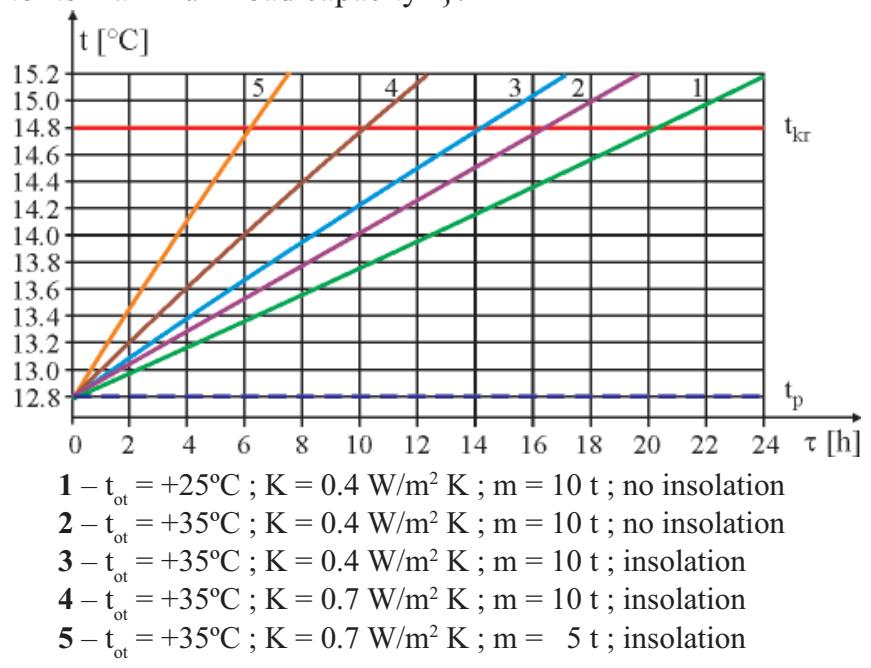

Fig. 5. Rate of rise of temperature of the cargo (bananas) contained in the reefer container cut-off from electricity supply source during its storage on sea port store place. $\boldsymbol{t}$-mean temperature of cargo (bananas) in the reefer container $\left[{ }^{\circ} \mathrm{C}\right], \boldsymbol{\tau}$ - period of cutting-off the container from electricity supply source $[h], \boldsymbol{t}_{\text {ot }}$ - ambient temperature of the container $\left[{ }^{\circ} \mathrm{C}\right], \boldsymbol{K}$-overall heattransfer coefficient of the container $\left[\mathrm{W} / \mathrm{m}^{2} \cdot \mathrm{K}\right], \boldsymbol{m}$-mass of cargo inside the container $[t], \boldsymbol{t}_{\boldsymbol{k} r}$ - critical temperature at which ripening process of bananas starts $\left[{ }^{\circ} \mathrm{C}\right], \mathrm{acc} .[14], t$-recommended temperature for transport of bananas $\left[{ }^{\circ} \mathrm{C}\right]$ 
For short periods of lack of the electricity supply the temperature rise function is almost linear, however in a longer time scale it can be observed that the temperature rise curve is an exponential function in compliance with $[6,11,15]$ and as clearly seen in Fig. 6.

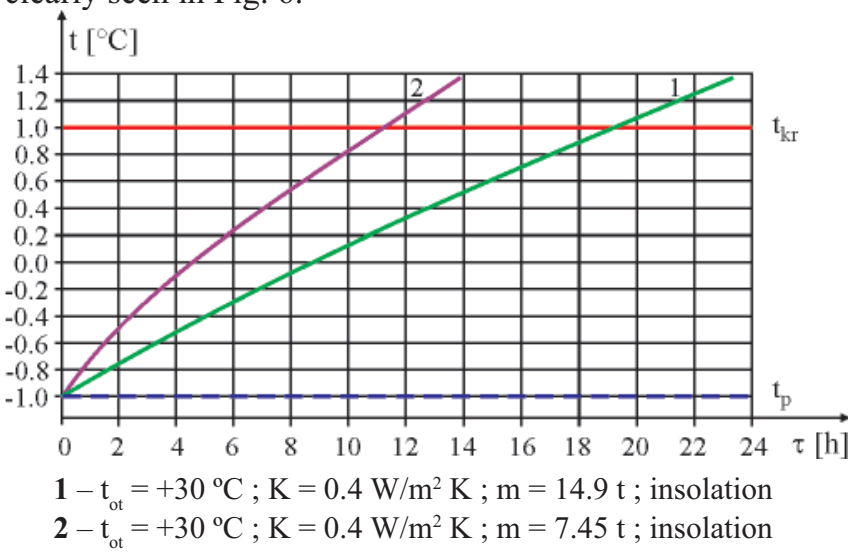

Fig. 6. Rate of rise of temperature of the cargo (pears) contained in the reefer container cutt-off from electricity supply source during its storage on sea port store place. $\boldsymbol{t}$-mean temperature of cargo (pears) in the reefer container $\left[{ }^{\circ} \mathrm{C}\right], \boldsymbol{\tau}$ - period of cutting-off the container from electricity supply source $[h], \boldsymbol{t}_{\text {ot }}$-ambient temperature of the container $\left[{ }^{\circ} \mathrm{C}\right], \boldsymbol{K}$-overall heattransfer coefficient of the container $\left[\mathrm{W} / \mathrm{m}^{2} \cdot \mathrm{K}\right], \boldsymbol{m}$ - mass of cargo inside the container $[t], \boldsymbol{t}_{\boldsymbol{k} r}$ - critical temperature $\left[{ }^{\circ} \mathrm{C}\right], \boldsymbol{t}_{p}$-recommended temperature for transport of pears $\left[{ }^{\circ} \mathrm{C}\right]$, acc. [9]

In the case of 40' container rate of cargo temperature rise is somewhat lower because of a greater mass of cargo. In Fig. 6 are presented results of calculations of rise of temperature of pears contained in the $40^{\prime}$ container cut-off from the electricity supply source.

Similar situation can be observed in the case of cargo cooling process at a very low ambient temperature (Fig. 7). The container filled with grapes, left without electricity supply in the ambient temperature of $-20^{\circ} \mathrm{C}$, is very fast cooled down. Just after $12 \div 24 \mathrm{~h}$ the cargo may appear frozen through. Moreover, in contrast to the case of bananas, consequences of the situation are disastrous as frozen grapes leave their commercial merits [6]. In the case of opening the gate of the container the above mentioned periods would be even shorter, i.e. risk level of cargo quality loss rises even more.

The results presented in Fig. 5, 6, and 7, were obtained under the simplifying assumption on uniformity of temperature

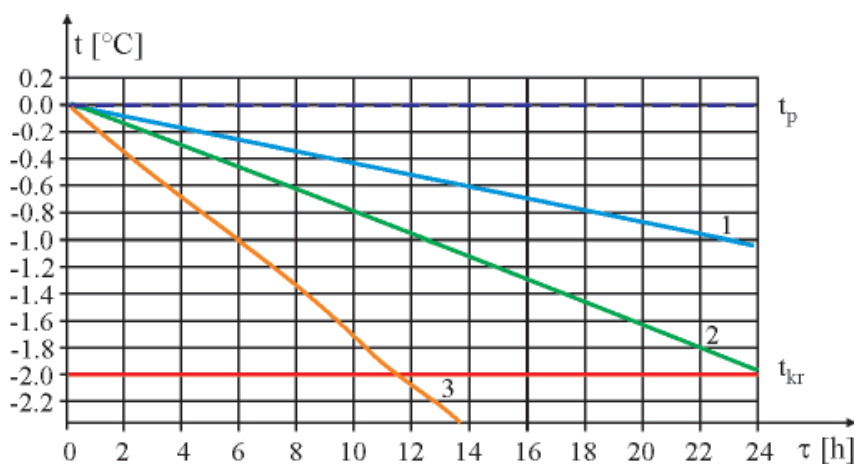

$1-\mathrm{t}=-20^{\circ} \mathrm{C} ; \mathrm{K}=0.4 \mathrm{~W} / \mathrm{m}^{2} \mathrm{~K} ; \mathrm{m}=10 \mathrm{t}$; no insolation $2-\mathrm{t}_{\mathrm{ot}}=-20^{\circ} \mathrm{C} ; \mathrm{K}=0.7 \mathrm{~W} / \mathrm{m}^{2} \mathrm{~K} ; \mathrm{m}=10 \mathrm{t}$; no insolation

$3-\mathrm{t}_{\mathrm{ot}}=-20^{\circ} \mathrm{C} ; \mathrm{K}=0.7 \mathrm{~W} / \mathrm{m}^{2} \mathrm{~K} ; \mathrm{m}=5 \mathrm{t}$; no insolation

Fig. 7. Rate of rise of temperature of the cargo (grapes) contained in the reefer container cutt-off from electricity supply source during its storage on sea port store place. $\boldsymbol{t}$-mean temperature of cargo (grapes) in the reefer container $\left[{ }^{\circ} \mathrm{C}\right], \boldsymbol{\tau}$ - period of cutting-off the container from electricity supply source $[h], \boldsymbol{t}_{o t}$ - ambient temperature of the container $\left[{ }^{\circ} \mathrm{C}\right], \boldsymbol{K}$ - overall heattransfer coefficient of the container $\left[\mathrm{W} / \mathrm{m}^{2} \cdot \mathrm{K}\right], \boldsymbol{m}$-mass of cargo inside the container $[t] \boldsymbol{t}_{\boldsymbol{k}}$ - freezing temperature of grapes (critical temperature) $\left[{ }^{\circ} \mathrm{C}\right]$, $\boldsymbol{t}_{p}$ - recommended temperature for transport of grapes $\left[{ }^{\circ} \mathrm{C}\right]$ distribution over whole volume of the container. When the container is cut-off from the electricity supply source the fans which have to ensure the above mentioned uniformity, are also switched off, hence the temperature field inside the container becomes very non-uniform, especially in the case of rise of temperature of cargo, i.e. when $t_{o t}>t_{p}$. Heating the container from the top by sunshine makes natural convection of the air through the gaps between stocks of cartboard boxes placed on pallets, difficult (Fig. 8). As a result, the outer layers of cartboard boxes full of cargo (e.g. bananas), marked red and orange, have a higher temperature than those placed in the middle, and the calculated delay of heating the inner cartboard boxes as compared with the outer ones amounts from $4 \mathrm{~h}$ to $8 \mathrm{~h}$. Taking into account the phenomenon, one can assume, for doing more precise calculations, that during the first $6 \div 10 \mathrm{~h}$ after cut-off the container from the electricity supply the whole outer heat flux is absorbed by the outer layers of cartboard boxes and does not reach their inner layers.

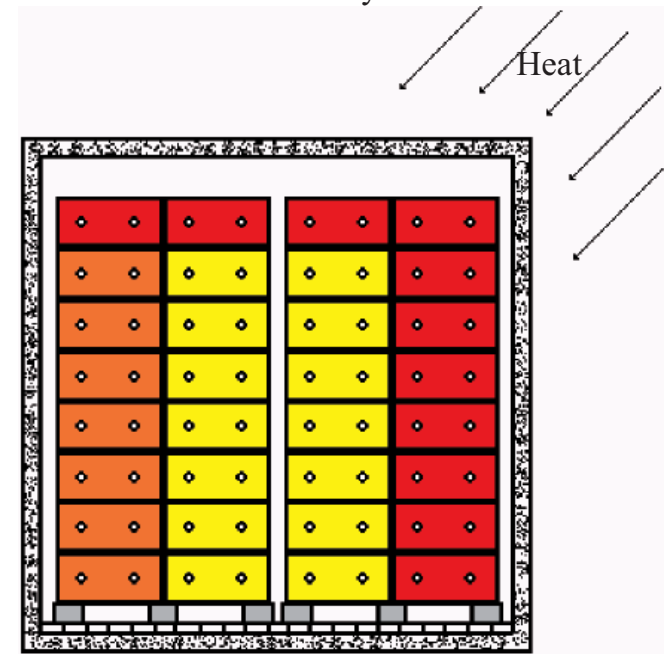

Fig. 8. Schematic diagram of arrangement of cartboard boxes filled with bananas in the reefer container, to be used in calculations of heat balance with taking into account non-uniformity of temperature inside the container

The calculation results where the temperature nonuniformity inside the container has been taken into account, are presented in Fig. 9. Like previously, for the calculations the standard stowage of 20' container: 10 pallets each loaded

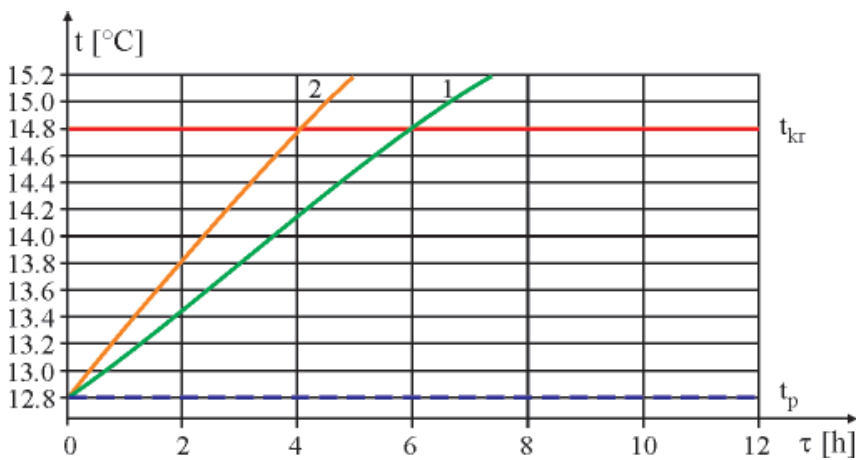

$\mathbf{1}-\mathrm{t}_{\mathrm{ot}}=+35^{\circ} \mathrm{C} ; \mathrm{K}=0.4 \mathrm{~W} / \mathrm{m}^{2} \mathrm{~K} ; \mathrm{m}=8.64 \mathrm{t}$; no insolation $2-\mathrm{t}_{\mathrm{ot}}=+35^{\circ} \mathrm{C} ; \mathrm{K}=0.7 \mathrm{~W} / \mathrm{m}^{2} \mathrm{~K} ; \mathrm{m}=8.64 \mathrm{t}$; no insolation

Fig. 9. Rate of rise of temperature of the cargo (bananas) in the upper layer of cartboard boxes (marked red in Fig. 8) inside the reefer container cutt-off from electricity supply source, with taking into account temperature non-uniformity in its interior. $\boldsymbol{t}$-mean temperature of the cargo (bananas) in a selected layer of cartboard boxes in the reefer container $\left[{ }^{\circ} \mathrm{C}\right], \boldsymbol{\tau}$ - period of cutting-off the container from electricity supply source $[h], t$-ambient temperature of the container $\left[{ }^{\circ} \mathrm{C}\right], \boldsymbol{K}$-overall heat-transfer coefficient of the container $\left[\mathrm{W} / \mathrm{m}^{2} \cdot \mathrm{K}\right], \boldsymbol{m}$ - mass of cargo inside the container $[t]$,

$\boldsymbol{t}_{\boldsymbol{k} r}-$ critical temperature at which ripening process of bananas starts $\left[{ }^{\circ} \mathrm{C}\right]$, $\boldsymbol{t}_{\boldsymbol{p}}$ - recommended temperature for transport of bananas $\left[{ }^{\circ} \mathrm{C}\right]$ 
with 48 cartboard boxes filled with $18 \mathrm{~kg}$ of bananas each,was assumed. Already within $4 \div 6 \mathrm{~h}$ after cutting-off the container from the electricity supply, temperature of bananas in the outer cartboard boxes was higher than allowable. Hence, to avoid loss of cargo quality the period of cutting-off the container from the electricity supply source should be not greater than $4 \mathrm{~h}$. The presented results are convergent with the results of experiments on cooling non-uniformity of bananas in ship's hold [12].

In the remaining calculation examples the taking into account of the temperature non-uniformity inside the container led to the period of reaching the critical temperature by outer layers of cartboard boxes $2 \div 2.5$ times shorter as compared with that obtained in the preceding calculations.

\section{SUMMARY}

The cutting-off of reefer container from electricity supply source, independing on its cause, should be considered a serious extraordinary situation which can quickly lead to loss of quality merits of refrigerated cargoes. On number and period of the cutting-offs an essential influence has a way of servicing the reefer container and sequence of servicing operations realized in sea port.

Below, a few recommendations for the servicing of reefer containers in sea ports are proposed:

O Sensitivity of refrigerated cargo to temeperature changes should be crucial criterion in designing its servicing chains. It should be tried to shorten the periods of cutting-off the container from electricity supply source, as much as possible.

To the servicing of loaded reefer containers in ports to apply the following servicing chain is not recommended: unloading, storing on quay, and next loading it onto a transport vehicle, transporting over port area, veterinary control, and moving it at least onto a store place. The so designed chain is characteristic of an extended period of container's cutting-off from electricity supply source.

$O$ If the servicing of reefer containers is carried out in summer (container's refrigerating unit operates according to refrigeration mode) then the port servicing chain should be designed and realized so as the operations associated with cutting-off the container from electricity supply source to be realized during the hours of the daily lowest ambient temperature.

If the servicing of reefer containers is carried out in winter at mean ambient temperature lower by more than $10{ }^{\circ} \mathrm{C}$ from transport temperature (container's refrigerating unit operates according to heating mode) then the operations associated with cutting-off the container from electricity supply source should be realized during the hours of the daily highest ambient temperature, and any control of the container, associated with opening its gate on store place, should be avoided.

At lack of the electricity supply to the container filled with non-ventilated frozen cargo, only the temperature inside the container changes and in consequence that of cargo too. And, in the case of refrigerated cargoes, namely fruits and vegetables, apart from temperature changes, air exchange becomes impossible (external and internal ventilation), that leads to a higher risk level of loss of cargo quality. Containers filled with such cargoes should be specially carefully serviced by port personnel.

$O$ Reefer containers and their port terminals should be equipped with devices for remote transmission / reception and processing of current information on climatic conditions inside the containers.
This paper presents only certain typical situations which may lead to loss of quality of refrigerated cargo transported in reefer containers. In order to perform a comprehensive analysis of simultaneous influence of various risk factors in particular servicing chains of the reefer container in port, to apply appropriate mathematical tools is necessary. In the Chair of Logistics and Transport Economy, Szczecin University of Technology, reserch is carried out on application of fuzzy logic to the problem in question; their results will be published in the future. The taking into account of all risk factors in planning the operations of servicing the refrigerated cargoes in port will make it possible to minimize probability of occurrence of extraordinary situations and this way to improve quality of functioning the cold chain.

\section{BIBLIOGRAPHY}

1. Bonca Z., Dziubek R.: Construction and operation of reefer containers (in Polish), WSM (Gdynia Maritime University), Gdynia, 1994

2. Container Handbook. Cargo loss prevention - information from German marine insurers, GDV, Berlin, 2007

3. The journal „Magazyn portowy” (Port store), Szczecin, $2000 \div 2007$

4. Filina L., Filin S.: Some problems of overload and storage of refrigeration containers in the port territory, Archives of Transport, vol. 16, issue 1, Warsaw, 2004

5. Filina L.: Methods of rationalization of servicing the containerized refrigerated cargoes in sea ports with application of fuzzy logic theory (in Polish), Doctor's thesis, Szczecin, 2007

6. Gruda Z., Postolski J.: Freezing the food products (in Polish), WNT (Scientific Technical Publishing House), Warszawa, 2000

7. Internal materials of ports Szczecin-Świnoujście, Gdańsk, Gdynia

8. Semenov I. N.: Risk management in maritime economy (in Polish), Vol. I, Szczecin 2003

9. Studziński A.: Operation of refrigerated ships (in Polish), Trademar, Gdynia, 2005

10. Zakrzewski B., Filin S., Konieczny P.: An analysis of energy consumption in refrigerated cargo sea transport. Polish Maritime Research, no. 4, 2000, Gdańsk

11.Алмаши Э., Эрдели Л., Шарой Т.: Быстрое замораживание пищевых продуктов (in Russian). Лег. и пищ. промышленность, 1981

12.Стефанович В.В., Комарницкий Б.В.: Системы охлаждения судовых рефрижераторных помещений (in Russian). Судостроение, Ленинград, 1984

13.Транспортировка и хранение тропических плодов (in Russian), Под ред. И.Г.Чумака. ДП «Рефпринтинфо», Одесса, 2004

14.Филина Л.С. Филин С.О.: Организация дозревания и транспортировки бананов на конечных стадиях холодильной цепи, Холодильный бизнес, № 2, 2002, с. 20-22

15.Чижов Г.Б.: Теплофизические прочессы в холодильной технологии пищевых продуктов (in Russian). М.: Пищевая промышленность, 1979.

\section{CONTACT WITH THE AUTHORS}

Lyudmyla Filina, Ph. D. Sergiy Filin, Prof.

Faculty of Marine Technology

Szczecin University of Technology

AL. Piastów 41,

71-065 Szczecin, POLAND

e-mail: lufilina@ps.pl 